\title{
Edukasi Pentingnya Disiplin Protokol Kesehatan di Tengah Pandemic COVID-19 pada Jemaat GPM Eden Kudamati
}

\author{
Helena Berhitu, Stensya Parera, Prily Sopacua, Yunet Salenussa, Regina Bembuain, \& \\ Johan Robert Saimima*
}

Universitas Kristen Indonesia Maluku, Indonesia

\begin{abstract}
Jemaat GPM Eden merupakan jemaat yang dilembagakan dari jemaat Rehoboth pada tanggal 12 februari 2012 yang dilakukan melalui tahap yang panjang. Yang mana tahun 2001 melalui persidangan ke 17 jemaat GPM Rehoboth di gedung gereja Getsemani diputuskan untuk dilakukan pemekaran jemaat, mengingat luasnya wilayah pelayanan dan jumlah anggota jemaat GPM rehobot yang terus bertambah. Dan dalam perjalanan waktu sampai sekarang, jemaat GPM Eden mengalami perkembangan baik dari pertambahan jumlah umat, unit dan sektor secara keseluruhan. Sesuai dengan keadaan yang terjadi pada saat ini juga dapat kita ketahui bahwa bangsa ini sedang dilanda dengan adanya COVID-19 dimana ditambah lagi dengan adanya varian baru yaitu varian delta. Hal ini dirasakan di kota Ambon terlebih khusus juga pada jemaat GPM Eden yang tidak terlepas juga dari dampak penyebaran Virus Corona. Untuk menghindari angka penderita yang terus meningkat, maka pemerintah memberikan pembatasaan kegiatan yang menimbulkan keramaian, menjaga jarak dan menjaga hygenitas pada masyarakat dalam melakukan kegiatan sehari-hari yang dikenal dengan peraturan protokol kesehatan. Hal yang pertama terlihat adalah pada sisi kebersihan, dan juga memperhatikan protokol kesehatan. Oleh karena itu tujuan kegiatan pengabdian masyarakat ini adalah untuk mengingatkan dan membantu pemahaman masyarakat tentang pelaksanaan protokol kesehatan selama pendemi COVID-19 yaitu dengan melakukan pembagian masker, pembagian tempat sampah, pembuatan spanduk mengenai tata cara pemutusan mata rantai COVID-19 dan pentingnya vaksinasi, adanya juga program saberling, bahkan penyemprotan yang di lakukan dalam Jemaat GPM Eden.
\end{abstract}

Keywords: COVID-19; edukasi; protokol kesehatan.

\section{Introduction}

Badan Kesehatan Dunia (WHO) menyebutkan, pandemi adalah skala penyebaran penyakit yang terjadi secara global di seluruh dunia. Namun, ini tidak memiliki sangkut paut dengan perubahan pada karakteristik penyakitnya. suatu wabah sebagai pandemi artinya WHO memberi alarm pada pemerintah semua negara di dunia untuk meningkatkan kesiapsiagaan untuk mencegah maupun menangani wabah tersebut (Firmansyah \& Kardina, 2020; Jamil, 2020; Sebayang, 2020; Umah, 2020; Mukaromah, 2020) Oleh sebab itu pemerintah mengelurakan beberapa kebijakan terkait pandemic ini yaitu dengan menerapkan Physcal distancing (hysical distancing atau pembatasan jarak fisik adalah upaya yang dilakukan untuk mengendalikan penyebaran infeksi virus Corona dan mencegah COVID-19.) maka dalam mengikuti anjuran pemerintah semua kegiatan yang di lakukan sekarang hanya melalui online termasuk proses pembelajar baik TK sampai pada Perguruan Tinggi .

\footnotetext{
* Corresponding author:

E-mail address: saimimajohn@gmail.com
} 
Pada Perguruan Kuliah kerja nyata tetap wajib di lakukan oleh Mahasiswa akhir. Kuliah Kerja Nyata (KKN) merupakan bentuk kegiatan pengabdian kepada masyarakat oleh mahasiswa dengan pendekatan pastoral dan sektoral pada waktu dan daerah tertentu. Kuliah Kerja Nyata (KKN) Universitas Kristen Indonesia Maluku (UKIM) pada masa pandemi ini diprogramkan untuk dilaksanakan pada kawasan tempat tinggal mahasiswa sehingga mempermudah pelaksanaan program kerja yang direncanakan serta mempermudah koordinasi dengan jemaat/masyarakat terkait. Mahasiswa juga didampingi secara online untuk bagaimana memprogramkan kegiatan-kegiatan serta menulis kronologis hasilnya berupa artikel hasil pengabdian masyarakat (Touwely, et.al., 2019). Universitas bersama dengan pihak- pihak terkait secara keseluruhan melibatkan mahasiswa KKN dalam menjadi penggerak untuk mensosialisasikan pencegahan COVID-19 (Corona Virus) kepada masyarakat tetapi dengan selalu mengikuti anjurananjuran yang di buat oleh pemerintah dengan selalu mengikuti protocol kesehatan. Program-program kegiatan yang direncanakan selama KKN pada dasarnya bertumpuk pada persoalan nyata di lapangan. Program tersebut dapat dilaksanakan sesuai dengan daya dukung sumber daya yang tersedia di lapangan. Keterlibatan mahasiswa dan masyarakat dalam setiap program mutlak diperlukan, yaitu dari perencanaan program, pelaksanaan, upaya pendanaan, dan evaluasi hasil. Tujuan utama dari KKN di tengah pandemic COVID-19 yaitu mengupayakan masyarakat untuk menwujudkan pentingnya disiplin untuk mengikuti protocol kesehatan di tengah pandemic COVID -19.

\section{Permasalahan Prioritas Mitra}

Beberapa permasalahan yang ada pada mitra (Jemaat GPM Eden), adalah sebagai berikut:

1) Permasalahan utama bahwa sebagian Jemaat tidak menyadari akan pentingnya Kebersihan dan protokol kesehatan dalam hal ini rajin mencuci tangan, menjaga jarak, memakai masker saat keluar rumah.

2) Kurangnya pemahaman jemaat tentang cara mencegah/memutuskan dan penularan COVID-19, pada masa New-Normal yang telah diterapkan oleh pemerintah.

3) Dampak COVID-19 membuat tingkat kesadaran jemaat dalam peribadatan dirumah berjalan tidak sesuai dengan saat beribadah di gedung gereja / tidak ada keseriusan.

4) Dampak COVID-19 ini juga menjadi bagian dalam perekonomian berjemaat yang titik fokusnya pada orangorang yang pekerjaan tidak tetap, tukang ojek, supir angkutan.

5) Sebagian jemaat tidak mau melakukan kegiatan vaksinasi akibat takut dan termakan isu-isu yang beredar

Masalah COVID-19 membuat jemaat hanya beraktifitas di rumah, tetapi juga ada yang melakukan aktifitas dalam pekerjaan yang hanya terbatas dengan waktu yang ditentukan oleh pemerintah dengan memperhatikan protokol kesehatan secara baik, tetapi berbeda dengan mereka yang terjun langsung dalam melihat pasien COVID-19 dalam hal ini para dokter, suster, perawat dll. Meski demikian kondisi jemaat suda melakukan berbagai hal terkait memutuskan mata rantai COVID-19 ini dengan cara-cara yang biasa dilakukan baik secara arahan, lewat corong-corong gereja. Kondisi ini juga membuat perekonomian semakin rendah dikalangan jemaat jika dilihat dari sebelum COVID-19 melanda akan Provinsi Maluku, masalah ekonomi juga turut dialami oleh jemaat.

\section{Solusi Permasalahan}

Untuk memecahkan permasalahan utama yang dihadapi oleh Mitra, maka solusi yang memungkinkan untuk dilaksanakan ialah :

1) Pembuatan Spanduk Protokol Pencegahan COVID-19 dan vaksinasi. Warga Jemaat Dapat Melihat Dan Mengerti Pentingnya Protokol Pencegahan COVID-19 Dan Pentingnya Vaksinasi

2) Penyemprotan Desinfektan Pada Gereja Induk Jemaat GPM Eden Kudamati. Jemaat Dapat Mematuhi Protokol Kesehatan Dan Menggunakan Fasilitas Yang Ada Untuk Mencegah Penyebaran COVID-19

3) Pembagian Masker Dalam Lingkungan Jemaat. Warga Jemaat Dapat Menggunakan Masker Untuk Mencegah Penyebaran Virus COVID-19.

4) Pengadaan Tempat Sampah Pada 4 Gereja Di Jemaat Eden Kudamati. Menyediakan Tempat Bagi Warga Jemaat Membuang Sampah Pada Saat Berada Di Lokasi Gereja.

5) Sabtu Bersih Lingkungan (Saberling) Pada Gedung Gereja Eden. Peningkatan Lingkungan Bersih Dan Sehat. 


\section{Metode Pelaksanaan}

Langkah-langkah kegiatan KKN-PPM yang telah disepakati oleh tim dan mitra yang dilakukan, diatur sebagai berikut:

\section{A. Tahap Persiapan:}

Tahap ini bertujuan untuk menggali informasi dalam rangka mendapatkan solusi permasalahan yang efektif dengan proses penyelesaian masalah yang efisien. Ada beberapa kegiatan yang dilaksanakan yaitu :

1) Berdiskusi dengan Jemaat Eden berkaitan dengan pengembangan Jemaat.

2) Tim KKN melakukan pendekatan dengan bagian perlengkapan dalam hal ini sebagai Mitra, guna mendapat informasi berkaitan dengan program-progam kerja yang TIM KKN akan laksanakan.

3) Tim KKN melakukan observasi lapangan, untuk mengetahui kebutuhan volume serta anggaran yang akan dibutukhan dalam pelaksaaan kegiatan KKN.

B. Tahap Pelaksanaan:

1) Pembelian tempat sampah, dan diberikan kepada jemaat sebagai salah satu cenderamatah untuk jemaat. Tetap pembelian tempat sampah juga bertujuan untuk masyarakat bisa tetap menjaga lingkungan,membuang sampah pada tempatnya. Kegiatan ini dilakukan oleh Mahasiswa KKN dan juga dibantu oleh para tuagama untuk lokasi ditarunya tempat-tempat sampah.

2) Pembagian masker yang berolakasi di jemaat GPM eden kudamati. Kegiatan ini dilakukan oleh Mahasiswa KKN. Kegiatan ini bertujuan untuk mengadvokasi masyarakat untuk tetap mematuhi protokol kesehatan ditengah pandemi COVID-19 sekarang ini. Pembagian masker diberkan kepada tukang ojek, pedagang kecil, supir oto, ataupun kepada siapa saja yang tidak menggunakan masker.

3) Pemasangan spanduk. Kegiatan ini dilakukan oleh Mahasiswa KKN, dimana kegiatan ini bertujuan juga untuk mengadvokasi masyarakat terkait pentingnya $5 \mathrm{M}$ dan juga vaksinasi ditengah pandemic sekarang ini. Karena kelompok kami tidak bisa melakukan sosialiasi karena kondisi COVID, sehingga kami melakukan advokasi melalui spanduk-spanduk yang kami pasang.

4) Penyemprotan disenfektan dan bersih lingkungan. Kegiatan ini dilakukan bersama oleh Mahasiswa KKN dan juga tuagama. Kegiatan ini bertujuan untuk mengadvokasi masyarakat agar tetap menjaga kebersihan, menjaga kesehatan selama pandemic COVID-19. Penyemprotan bertujuan untuk menjaga lingkungan tetap bersih dan terhindar dari virus-virus.

C. Tahap Evaluasi Program:

1) Kegiatan ini akan terus dievaluasi sesuai dengan tingkat keberhasilan dan keberlanjutan oleh Mahasiswa KKN dan juga Instruktur. Baik saat melaksankan program dan juga selesai melaksanakan program.

2) Kami terus berkoodinasi baik dengan instruktur, maupun dengan Ketua Majelis Jemaat GPM Eden kudamati terkait situasi maupun masalah tentang COVID-19 yang terjadi di dalam jemaat.

3) Kami juga mengharapkan kerja sama yang baik dari instruktur dan juga dari Semua anggota jemaat eden dalam menopang kegiatan yang kami lakukan.

\section{Hasil dan Luaran yang Dicapai}

Berdasarkan kesepakatan tim bersama dengan mitra jemaat GPM eden kudamati maka dengan begitu kami mahasiswa fakultas teologi UKIM yang sedang berada pada tahapan pelaksanaan program KKN di jemaat Eden. Berdasarkan hal itu, maka dilakukan beberapa kegiatan dari hasil perencanaan sebagai bagian dari program KKN yang mana juga dilihat dari keadaan jemaat.

Untuk itu Kegiatan dan hasil pelaksanaan program KKN di jemaat Eden Kudamati ini ditujukan untuk mendapatkan luaran yang diharapkan. Kegiatan dan hasilnya dapat diungkapkan sebagai berikut:

\section{Pelakasaan Kegiatan Pembagian Masker}

Pada tahap pelakasaan kegiatan pembagian masker ini dilakukan oleh mahasiswa KKN yang mana mulai dilakukan pada tempat-tempat yang ramai seperti pangakalan ojek dan juga di jalan- jalan terkhusnya lingkungan jemaat Eden. 
Pelakasanaan kegiatan ini berlangsung dua kali yakni pada minggu ketiga di bulan juli pada pukul 10:00 - 12:00 WIT. Pembagian masker ini dilakukan kepada jemaat Eden kudamati terkhususnya bagi mereka yang keluar rumah tidak memakai masker atau tidak taat protocol kesehatan.
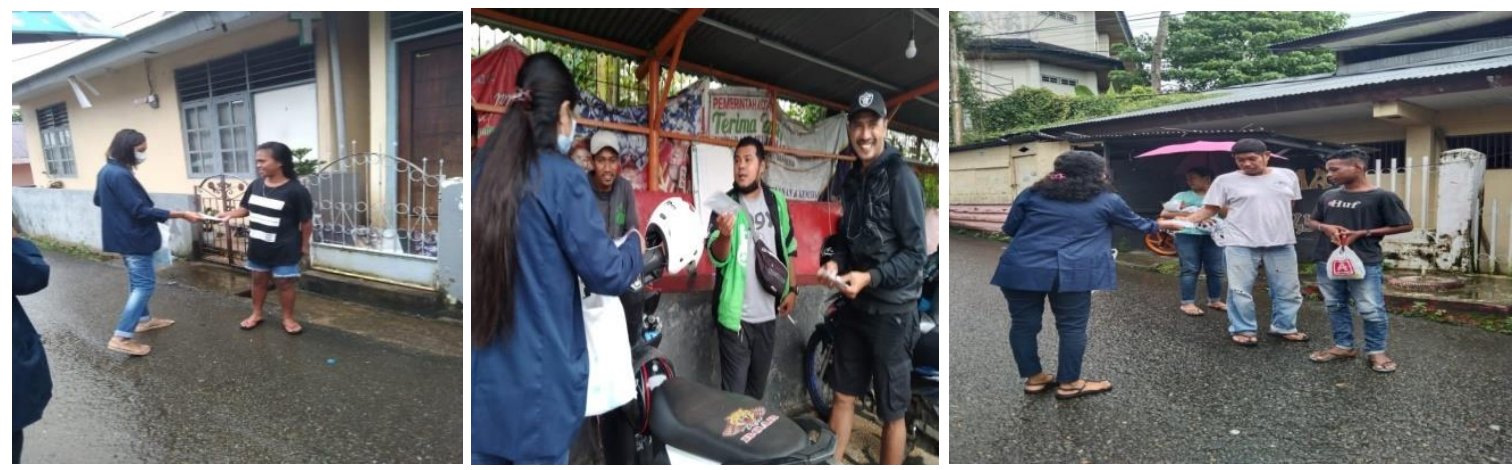

Gambar 1. Pembagian Masker Kepada Warga Jemaat GPM Eden Kudamati Yang Tidak Menggunakan Masker Saat Keluar Rumah

Pada tahap kegiatan ini, pemasangan spaduk dilakukan dalam hal memberikan edukasi tentang pentingnya mematuhi protocol kesehatan dalam penerapan 5M dan juga mewujudkan masyarakat yang sehat dan produktif dengan vaksinasi yang berguna bangun imunitas tubuh. Pemasangan spanduk ini dilakukan sebagai ganti sosialisasi yang tidak dapat terlaksana karena situasi dan kodisi serta penerapan PPKM yang dilakukan oleh pemerintah kota Ambon sehinga jika dilakukan secara online maupun lewat toa pun tidak efektif kerena melihat kondisi dan situasi. Dengan begitu sehingga sosialisasi yang awalnya sudah dirancangkan tidak dapat dilakukan. Pelkasanaan kegaiatan pemasangan spanduk ini dilakukan pada minggu kedua bulan Agustus 2021 pukul 11:00 - 15:26 WIT. Pemasangn spanduk ini dilakukan oleh mahasiswa KKN dan dibantu juga oleh tuagama di jemaat Eden dan pemasangan spanduk ini dipasangkan di depan gereja Eden Kudamati.
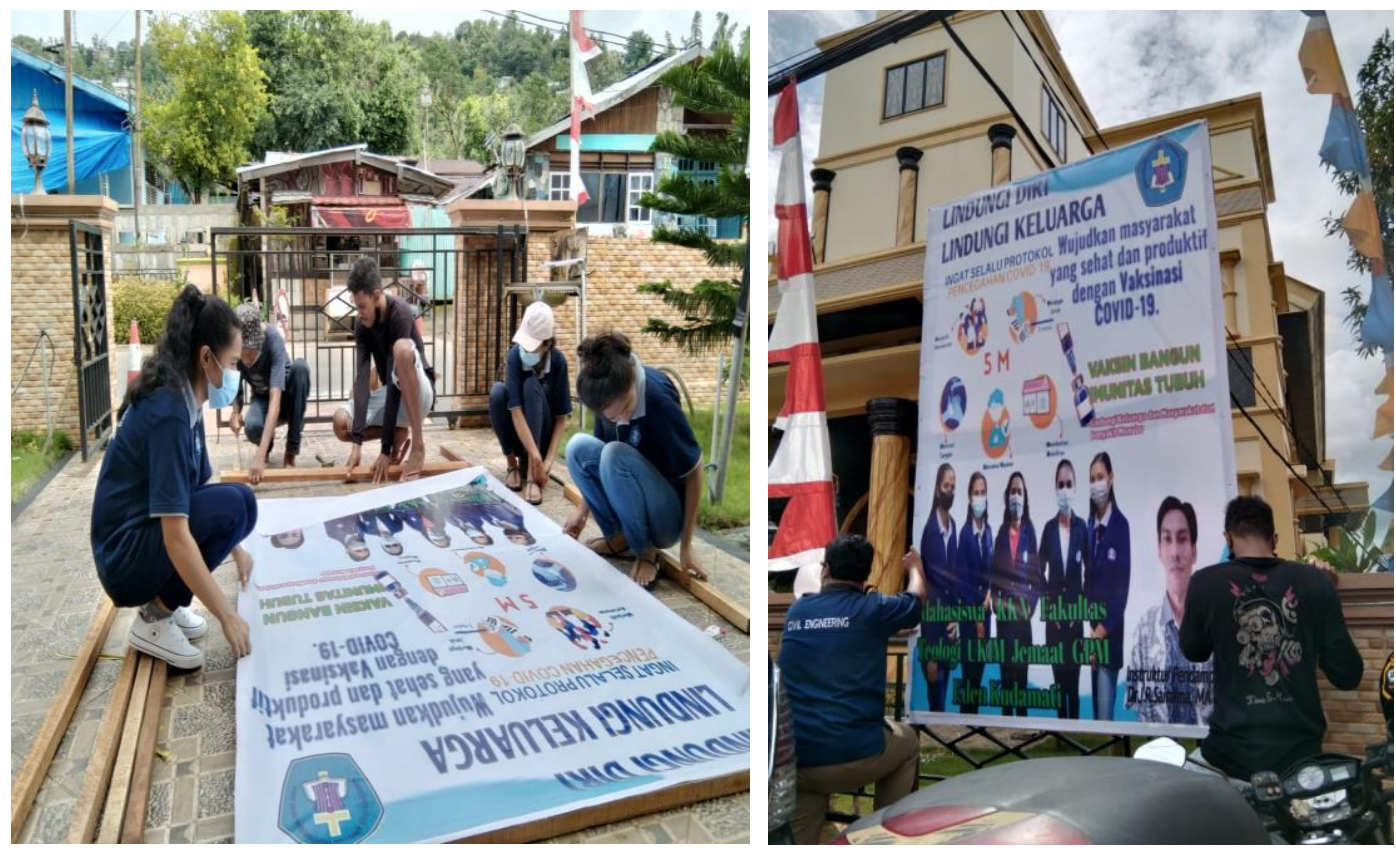

Gambar 2. Pemasangan spanduk didepan gedung gereja Eden Kudamati 


\section{Pengadaan Tempat Sampah}

Pengadaan tempat sampah guna untuk jemaat tetap membuang sampah pada tempatnya, pada saat berada di gereja.

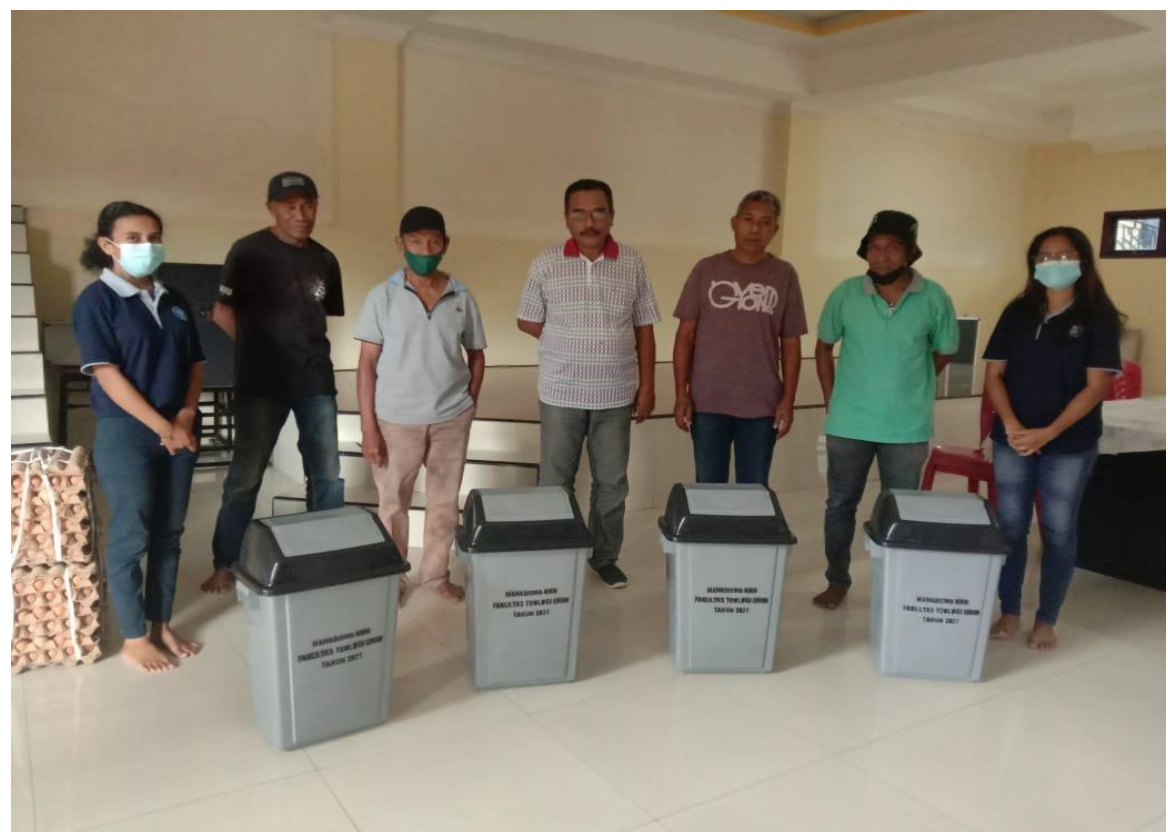

Gambar 3. Pemberina tempat sampah kepada gedung gereja Eden kudamati

\section{Penyemprotan dan Saberling atau bersih lingkungan.}

Pada tahap kegiatan ini dilakukan pada minggu kedua di bulan Agustus pada pukul 10:00-13:15 WIT. Kegiatan penyemprotan dan saberling ini dilakukan oleh mahsasiwa KKN bersama tuagama jemaat Eden yang turut membantu dalam pelaksaan kegiatan tersebut. Hal ini dikarenakan kondisi cuaca yang tidak memungkinkan sehingga dibeberapa minggu sebelumnya terjadi pembatalan dan baru terlaksana pada minggu tersebut. Kegiatan saberling yang dilakukan bertujuan membantu memelihara lingkungan yang bersih dan sehat. Sedangkan tujuan penyemprotan disenfekatan yang dilakuakan di beberapa sektor jemaat Eden ini juga sebagai langkah pencegahan meluasnya virus korona serta usaha meningkatkan kebersihan untuk mencega penyebaran virus corona (COVID-19) dilingkungan sektor-sektor di jemaat Eden. Namun meilihat cuaca dengan curah hujan yang cukup tinggi dan juga mengingat masa KKN yang hamper selesai sehingga saberling atau bersih lingkungan dan penyemprotan tidak dapat dilakukan di sektor-sektor tetapi di lakukan di dalam gedung gereja dan lingkungan sekita gereja.
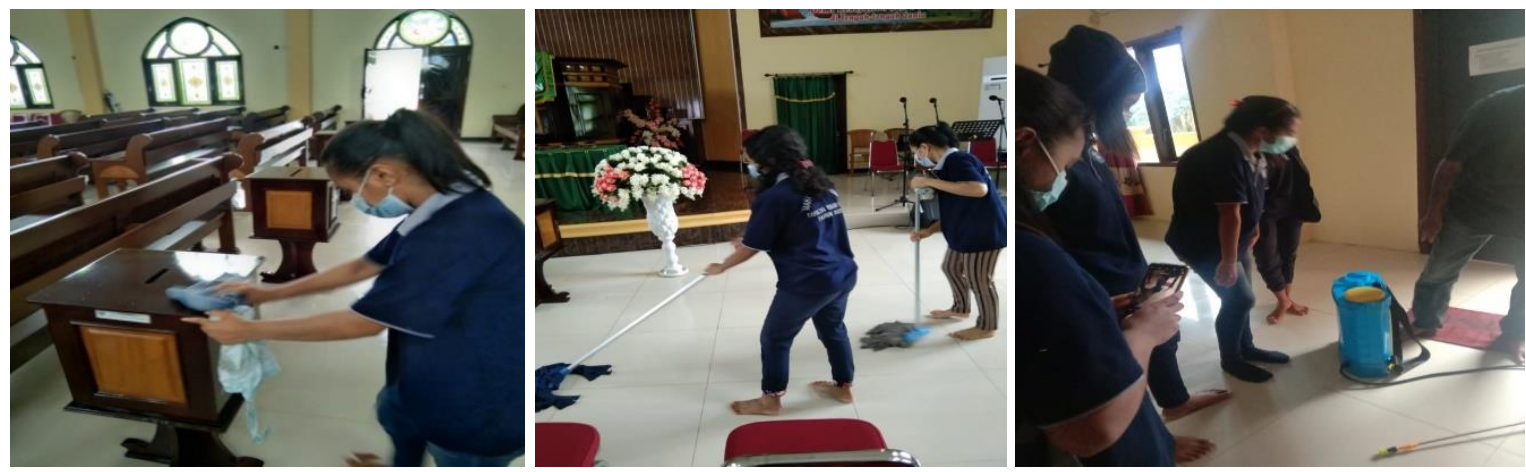

Gambar 4. Penyemprotan disenfektan sekaligus pembersihan gedung gereja Eden kudamati 
Luaran yang dihasilkan dari kegiatan ini dilakuan dan disesuaikan dengan keadaan situasi dan kondisi pada jemaat Eden. Dan kegiatan yang dilakukanpun mendapat respon baik dari mitra. Dan sebagaimana yang telah dijelaskan di atas, kegiatan-kegiatan yang telah dilaksanakan dan hasil diperoleh dari pelaksanaan program KKN di jemaat Eden Kudamati dimaksudkan untuk mendapatkan luaran yang ditergetkan sesuai target luarannya.

\section{Kesimpulan}

Penerapan perilaku hidup bersih, dengan mengutamakan kesehatan patuhi protokol kesehatan, serta mengikuti vaksinasi dalam mengatasi pandemik COVID-19 yang sedang terjadi terlebih khusus bagi jemaat GPM Eden, sangat penting bagi diri sendiri ataupun bagi orang lain serta lingkungan di sekitarnya. Tetap produktif di tengah pandemic COVID-19 sekarang ini sangatlah penting. Untuk itu masyarakat diajak untuk tetap hidup sehat, tetap melakukan halhal yang positif selama masa pandemic. Apa yang menjadi aturan yang telah dikeluarkan pemerinta patutlah dituruti, karena itu semua untuk kebaikan bersama. Tetap patuhi 5M agar semua dapat terhindar dari ancaman pandemic COVID-19.

\section{References}

Firmansyah, Y. \& Kardina, F. (2020). Pengaruh New Normal Ditengah Pandemi COVID-19 Terhadap Pengelolahan Sekolah dan Peserta Didik. Buana Ilmu, 4(2), 99-112.

Jamil, A. I. (2020). Peringatan WHO: Pandemi COVID Tahun Ini Jauh Lebih Mematikan daripada 2020, Jakarta: INews.id. Access: 17 August 2021. URL: https://www.inews.id/news/internasional/peringatan-who-pandemiCOVID-tahun-ini-jauh-lebih-mematikan-daripada-2020.

Mukaromah, V. F. (2020). Tiga Peringatan WHO: Lonjakan Kasus COVID-19 hingga Nasionalisme Vaksin, Jakarta: Kompas.com/Tren. $\quad$ Access: $17 \quad$ August $2021 . \quad$ URL: https://www.kompas.com/tren/read/2020/10/26/135000665/tiga-peringatan-terbaru-who--lonjakan-kasusCOVID-19-hingga-nasionalisme?page=all.

Sebayang, R. (2020). Peringatan WHO: Dunia Harus Siap Serangan Pandemi Baru Lagi, Jakarta: CNBC Indonesia. Access: 17 August 2021. URL: https://www.cnbcindonesia.com/tech/20200908061123-37-185061/peringatanwho-dunia-harus-siap-serangan-pandemi-baru-lagi.

Touwely, G. H., Nanuru, R. F., Laisila, M., \& Dandirwalu, R. (2019). Assistance on Writing Scientific Papers for Students of Nusaniwe Village. Indones. J. Cult. Community Dev., 4(1), 23-31, DOI: 10.21070/ijccd.v2i3.70.

Umah, A. (2020). Jangan Kaget, Ini Peringatan WHO Soal Pandemi Baru di Bumi, Jakarta: CNBC Indonesia. Access: 17 August 2021. URL: https://www.cnbcindonesia.com/tech/20200912090427-37-186280/jangan-kaget-iniperingatan-who-soal-pandemi-baru-di-bumi. 